Йзв. АН Эстонии. Геол., 1992, 41, 2, 73-80

УДК $553.985+553.982(474.2)$

Велло КАТТАЙ*, Борис КЛУБОВ**, Лора БАГДАСАРЯН ${ }^{* *}$, Калле СУУРОЯ***

\title{
НОВЫЕ ДАННЫЕ О БИТУМОНОСНОСТИ НИЖНЕПАЛЕОЗОЙСКИХ ОТЛОЖЕНИЙ О-Ва ХИИУМАА
}

В пределах территории острова выделены две зоны нанбольшего битумонакопления. Природные битумы в «Северной» зоне приурочены к отложениям среднего ордовика, в «Южной» - верхнего ордовика и нижнего силура. Вещественный состав битумов обеих зон близок. В целом их можно рассматривать как составляющие нормального гипергенного ряда изменения нафтидов: нефть - мальта - асфальт.

Настоящая статья продолжает серию публикаций (Каттай, Кундель, 1987; Клубов, Уров, 1988; Каттай, Клубов и др., 1990; Каттай, Кала и др., 1990; Каттай, 1990) о природных битумах (ПБ) Эстонии. Результаты полевых работ 1989-1990 гг. по южной части о-ва Хийумаа, а также данные лабораторных химико-битуминологических и микропалеонтологических исследований ПБ, выполненных во Всесоюзном нефтяном научно-исследовательском геологоразведочном институте, позволяют сделать определенные заключения о составе и закономерностях распределения локальных скоплений ПБ в пределах о-ва Хийумаа.

В территориальном отношении удалось выделить две зоны субширотного простирания нанбольшего битумонакопления (рис. 1). Одна из них (условно «Северная») расположена в северной части острова и связана с образованиями среднего ордовика. На востоке она ограничивается районом развития Кярдлаской структуры (КС), а в западном направлении распространяется под акваторию Балтийского моря. Наиболее битумонасыщенные породы вскрыты в скважинах, расположенных западнее КС. Общая мощность интервала битумосодержащих пород, охватывающего несколько стратиграфических горизонтов (преимущественно от кукрузеского до кейлаского) среднего ордовика, составляет по вертикали до 40-50 м. Ареал площадного распространения ПБ от более древних к более молодым образованиям постепенно смещается с запада на восток. Глубина залегания кровли битумоносной толщи (по первым проявлениям битумов в разрезе) изменяется от первых десятков метров на севере до $100-150$ м в средней части острова.

В районе КС, на гребне и склонах ее кольцевого вала, а также во внешней, примыкающей к нему зоне, ПБ вскрыты преимущественно в посткратерных карбонатных образованиях раквереского и набалаского горизонтов среднего-верхнего ордовика. Внутри кратера и далее, восточнее его, ПБ не встречены.

* Eesti Teaduste Akadeemia Geoloogia Instituut (Институг геологии Академии наук Эстонии). EE0105 Tallinn, Estonia pst. 7. Estonia.

** Всесоюзный нефтяной научно-исследовательский геологоразведочный институт. 191104 Санкт-Петербург, Литейный пр. 39.

*** Eesti Geoloogiakeskus (Эстонский геологический центр). EE0101 Tallinn, Pikk 67. Estonia. 


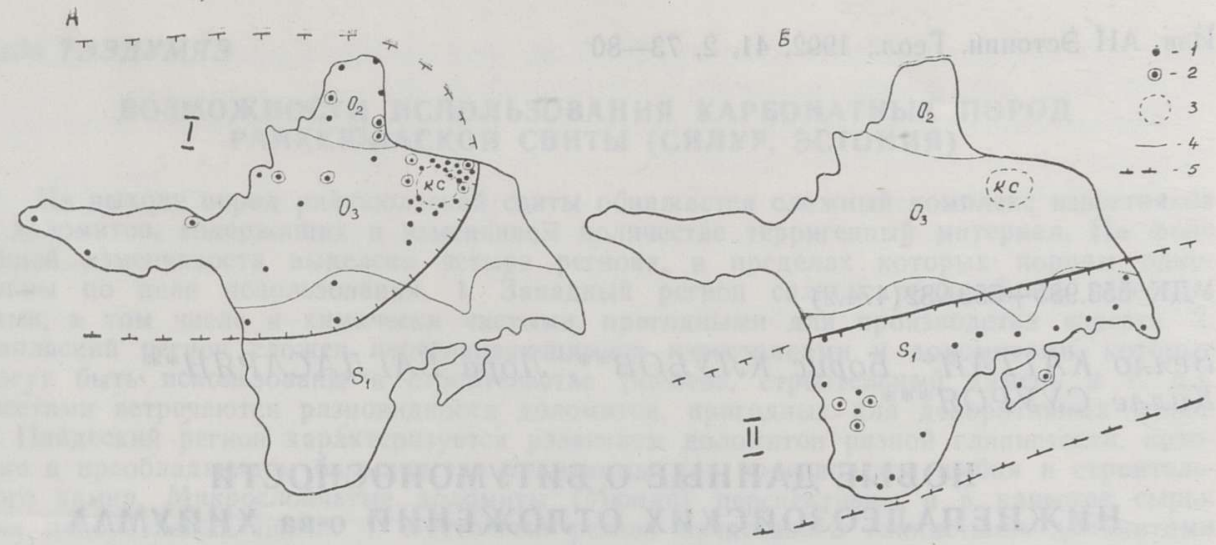

Рис. 1. Схема распространения битумопроявлений в отложениях среднего ордовика (А), верхнего ордовика и нижнего силура (Б). 1 - пункты битумопроявлений, 2 - опробованные битумопроявления, 3 - Кярдлаская структура, 4 - границы стратиграфических подразделений, 5 - зоны битумонакопления (I - «Северная», II - «Южная»).

Fig. 1. Distribution of bitumen occurrences in Middle Ordovician (A), Upper Ordovician and Lower Silurian (Б) sediments. 1 - points of bitumen occurrences, 2 - sampled bitumen occurrences, 3 - Kärdla structure, 4 - boundaries of stratigraphical units, 5 zones of bitumen accumulation (I - «Northern», II - «Southern»).

Повышенная битумонасыщенность в «Северной» зоне является, видимо, следствием миграции углеводородов (УВ) со стороны акватории Балтийского моря в направлении локального поднятия $\mathrm{KC}$, в сводовых частях которой проницаемость пород и коллекторские их свойства были лучше. На это указывает и общее увеличение битумонасыщенности пород в западном направлении, погружение толщи с охватом более древних осадочных образований (находки ПБ и в породах кундаского горизонта нижнего ордовика) и появление в разрезе жидких разностей битумов.

Другая зона битумопроявлений (условно «Южная») пересекает остров с запада на восток, продолжение ее прослеживается и на материковой части Эстонии. Общая мощность интервала, в пределах которого зафиксированы ПБ в образованиях верхнего ордовика (пиргуский, поркуниский горизонты) и нижнего силура (юуруский, райккюлаский), составляет от 10 до 40 м. Кровля этой толщи погружается в южном направлении на глубину от $10-20$ до $60-70$ м. Следует отметить, что в пределах «Южной» зоны в отложениях среднего ордовика ПБ нет.

Характер битумонасыщения в карбонатных породах «Северной» и «Южной» зон аналогичен. Әто пятна пропитки, полосы импрегнации битумом вдоль контактов известняков с прослоями мергелей, заполнение им пор и мелких каверн, примазки и корочки по стенкам трещин (фототаблица). Содержание ПБ не превышает по массе долей процента (табл. 1). Преобладают вязкие ПБ, твердые и жидкие отмечаются редко.

Наиболее высокая концентрация битума (около 10\%) характерна для маломощного прослоя песчаника в подошве идавереского горизонта $\left(\mathrm{O}_{2} i d\right)$ в «Северной» зоне, где отмечена сплошная и полосчатая пропитка твердым битумом (Каттай, 1990).

Интересным представляется тот факт, что в западной части «Южной» зоны ПБ обнаружены в биогермных известняках юуруского (хиллистеская пачка?) горизонта. Рифовые образования в виде линз с весьма изменчивой мощностью вскрыты здесь в двух скважинах. 
Реестр опробованных битумопроявлений по «Южной» зоне

Table 1

List of sampled bitumen occurrences along the "Southern" bitumen-bearing zone

\begin{tabular}{|c|c|c|c|c|}
\hline $\begin{array}{c}\text { Скважина, } \\
\text { проба }\end{array}$ & $\begin{array}{c}\text { Индекс горизонта } \\
\text { (глубина отбора } \\
\text { проб, м) }\end{array}$ & $\begin{array}{l}\text { Форма проявления } \\
\text { битума }\end{array}$ & 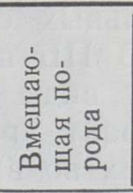 & $\begin{array}{c}\text { Содер- } \\
\text { жание } \\
\text { битума } \\
\text { породе, } \\
\% \text { (по } \\
\text { массе) }\end{array}$ \\
\hline $\begin{array}{l}\text { Кюлакюла К-29, } \\
1 \text {-я }\end{array}$ & $\mathrm{S}_{1} r k \quad(22,7)$ & $\begin{array}{l}\text { Пятнистая пропитка биту- } \\
\text { мом }\end{array}$ & $\begin{array}{l}\text { Извест- } \\
\text { няк }\end{array}$ & 0,48 \\
\hline Ласси К-39, 1-я & $\mathrm{S}_{1} j \mathrm{r} \quad(22,4)$ & $\begin{array}{l}\text { Заполнение пустот твердым } \\
\text { битумом }\end{array}$ & $\begin{array}{l}\text { Биогерм- } \\
\text { ный из- } \\
\text { вестняк }\end{array}$ & 3,23 \\
\hline Ласси К-39, 2-я & $S_{1} j r \quad(30,6)$ & $\begin{array}{l}\text { Заполнение пустот жидким } \\
\text { битумом }\end{array}$ & & 1,86 \\
\hline $\begin{array}{l}\text { Ванамыйза K-40, } \\
\text { 1-я }\end{array}$ & $\mathrm{O}_{3} p r \quad(56,1)$ & $\begin{array}{l}\text { Пятнистая пропитка биту- } \\
\text { мом }\end{array}$ & $\begin{array}{l}\text { Извест- } \\
\text { няк }\end{array}$ & 0,06 \\
\hline $\begin{array}{l}\text { Кассари } 371 \phi, \\
1-я\end{array}$ & $\mathrm{O}_{3}$ prg $(70,3)$ & $\begin{array}{l}\text { Вязкий битум в кавернах, } \\
\text { по трещинам }\end{array}$ & & 0,05 \\
\hline
\end{tabular}

П р и ме ч а н ие. Данные опробования битумопроявлений по «Северной» зоне см. Қаттай, 1990; Қаттай, Қлубов и др., 1990.

Мощность биогермных известняков в скв. Ласси К-39 с непосредственным выходом их под четвертичные отложения составляет более $12 \mathrm{~m}$. Отметим, что рифовые образования этого возраста известны и в восточной части острова, и в Западной Әстонии (Аалоэ, Эйнасто, 1970; Аалоэ, Нестор, 1977), однако ПБ в них зафиксированы не были.

Биогермные известняки сложены скелетными остатками рифостроящих организмов (табуляты, ругозы, строматопороидеи и др.), в которых пустые камеры кораллов и интервалы дробленых пород заполнены битумом различной консистенции. Судя по результатам изучения шлифов, битумы разной степени преобразованности представлены здесь, видимо, не менее чем двумя генерациями. Первая - это черный твердый ПБ, вторая - прозрачно-коричневые жидкие ПБ (фототаблица).

Содержание битума, по результатам опробования керна, составило $1,8-3,2 \%$ (табл. 1). Внутренние части скелетных остатков зачастую также покрыты вторичным мелко-среднезернистым кальцитом.

Наличие ПБ в «Южной» зоне в довольно узком стратиграфическом интервале и прослеживание их на материке можно, по всей вероятности, увязать с развитием рифовых образований, пористые биогермные известняки которых являются литологическими коллекторами. Поэтому можно полагать, что факт вскрытия (1905г.) в гидрогеологической скв. Ваэмла нефтеподобной жидкости, долго подвергавшийся сомнению (Scupin, 1924; Einpaul, 1961), мог на самом деле иметь место.

Проведенные микропалеонтологические исследования ПБ о-ва Хийумаа в целях выяснения их природы показали, что микрофоссилии растительного (акритархи), и животного (хитинозои) происхождения как в ПБ «Северной» зоны, так и во вмещающей их породе (средний ордовик) по видовому составу однотипны. Ископаемых остатков из более древних отложений не встречено. Причем ПБ значительно больше, чем вмещающая их порода, насыщены характерными для среднего ордовика органическими остатками. Это возможно лишь при длительной латеральной миграции нефти по пласту. Такие примеры 
зависимости концентрации и видовых соотношений микрофоссилий от условий и форм миграцци отмечены и в других регионах (Багдасарян, 1988, 1989).

Картина концентрации микрофоссилий в нижнесилурийских породах и в содержащихся в них битумах меняется на противоположную. В отдельных случаях даже состав растительных остатков не однотипен. В ПБ наряду с фоссилиями из нижнесилурийских отложений имеются виды хитинозой, характерные для ордовикских отложений. Такой факт присутствия в ПБ более древних микрофоссилий, отсутствующих во вмещающей породе, может указывать на привнос их из более древних образований.

В предыдущих публикациях (Каттай, Клубов и др., 1990; Каттай, 1990) приведены результаты изучения состава ПБ по «Северной» зоне. Выполненный комплекс химико-битуминологических исследований по битумам «Южной» зоны включал определения выхода битума, его элементного и группового составов, а также углеводородного состава масел (исполнители Е. В. Гарибьян, Т. Н. Абрамова, Е. М. Файзуллина, А. И. Шапиро и др.).

Как видно из рис. 2 и табл. 2, ПБ «Северной» и «Южной» имеют весьма близкий вещественный состав. В целом их можно рассматривать как составляющие нормального гипергенного ряда изменения нафтидов: нефть $\rightarrow$ мальта $\rightarrow$ асфальт. По мере перехода от осмоленной нефти к асфальтам в элементном составе ПБ происходит уменьшение содержания С, H и увеличение содержания гетероэлементов - S, O. В групповом их составе соответственно снижаются содержание масел и доля метаново-нафтеновых УВ, увеличивается содержание смол и асфальтенов (табл. 2).

В имеющихся публикациях (Люткевич, 1965; Паасикиви, Закашанский, 1965; Сакалаускас, 1968; Стумбур и др., 1982; и др.), краевые части Балтийской синеклизы (БС) в целом оцениваются как неперспективные с точки зрения нефтеносности. И действительно, в карбонатных толщах ордовика-силура нет хороших и емких гранулярных коллекторов, как нет и надежных изолирующих покрышек. Некоторое улучшение коллекторских свойств происходит за счет процессов доломитизации и выщелачивания пород, появления в разрезе рифовых

1. Полужидкий битум (темный фон) в пустотах кораллов в биогермных известняках юуруского горизонта $\left(\mathrm{S}_{1} j r\right)$. Умен. х 0,75. Скв. Ласси Қ-39, глубина 30,2 м.

2 3. Твердый битум в биогермных известняках юуруского горизонта ( $\left.\mathrm{S}_{1} j \mathrm{r}\right)$. Умен. х 0,75 . Скв. Ласси К-39, глубина 22,4 м.

4. Полосы пропитки дисперсным битумом нзвестняков райккюлаского горизонта $\left(\mathrm{S}_{1} r k\right)$. Натур. вел. Скв. К-84, глубина 39,8 м.

5. Қаемки пропитки битумом известняков вдоль контактов с тонкими прослоями мергелей в райккюласком горизонте $\left(\mathrm{S}_{1} k r\right)$. Умен. х 0,75 . Скв. Кюлакюла К-29, глубина 22,7 м.

6. Каемки и пятна пропитки дисперсным битумом известняков в райккюласком горизонте $\left(\mathrm{S}_{1} r k\right)$. Умен. х 0,5. Скв. Қ-81, глубина 39,5 м.

1. Half-liquid bitumen (dark colour) in coral cavities of boundstones of the Juuru Stage $\left(\mathrm{S}_{1} j r\right)$. Reduction $\times 0.75$. Lassi K-39 borehole, depth $30.2 \mathrm{~m}$.

2. 3. Solid bitumen in boundstones of the Juuru Stage $\left(\mathrm{S}_{1} j r\right)$. Reduction $\times 0.75$. Lassi K-39 borehole, depth $22.4 \mathrm{~m}$.

4. Limestone belts of the Raikküla Stage $\left(\mathrm{S}_{1} r k\right)$ impregnated with dispersed bitumen. Natural size. K-84 borehole, depth $39.8 \mathrm{~m}$.

5 . Contact lines of limestones impregnated with dispersed bitumen, with thin marlstone interlayers in the Raikküla Stage $\left(\mathrm{S}_{1} r k\right)$. Reduction $\times 0.75$. Külaküla K-29 borehole, depth $22.7 \mathrm{~m}$.

6 . Lines and patches of dispersed bitumen impregnation in limestones of the Raikküla Stage $\left(\mathrm{S}_{1} r k\right)$. Reduction $\times 0.5$. K-81 borehole, depth $39.5 \mathrm{~m}$. 

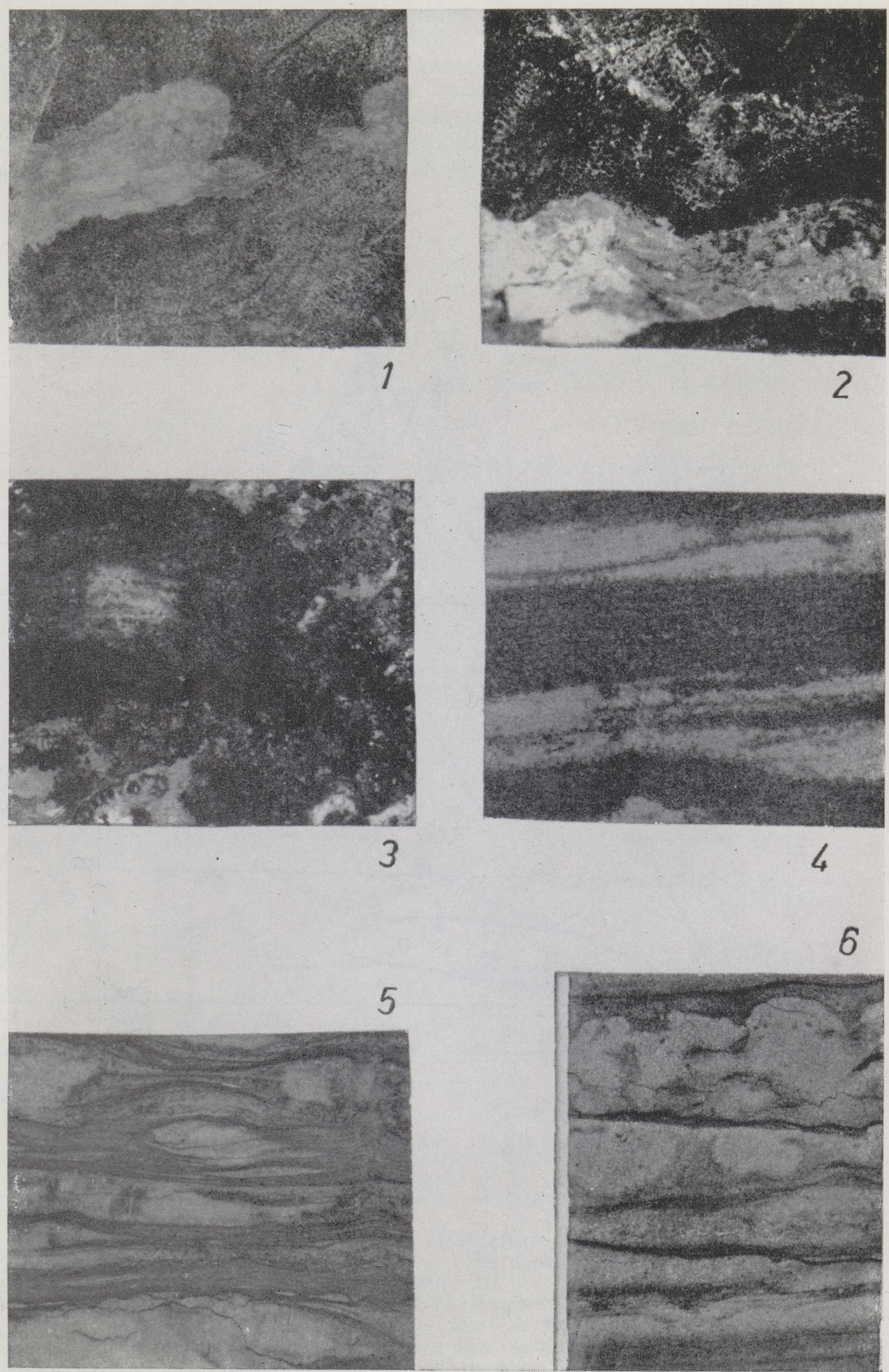

6

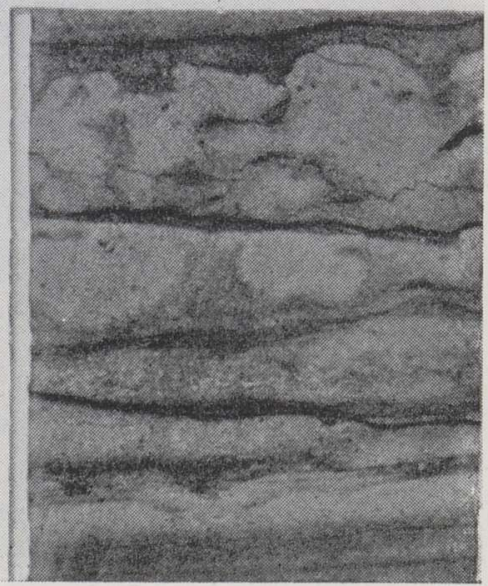



образований. Так, на западном борту БС на о-ве Готланд (Шведский сектор Балтики) в рифовых известняках верхнего ордовика в 80-х годах были открыты мелкие месторождения нефти, разрабатываемые в настоящее время (Кадунене и др., 1985). На юго-восточном борту синеклизы, в краевых ее частях, выделены рифогенные барьеры и одиночные органогенные постройки на разных стратиграфических уровнях с установленными нефтепроявлениями (Нефтяные месторождения Прибалтики, 1987). Все это в увязке с приведенными выше данными по проявлениям битумов о-ва Хийумаа с явной тенденцией

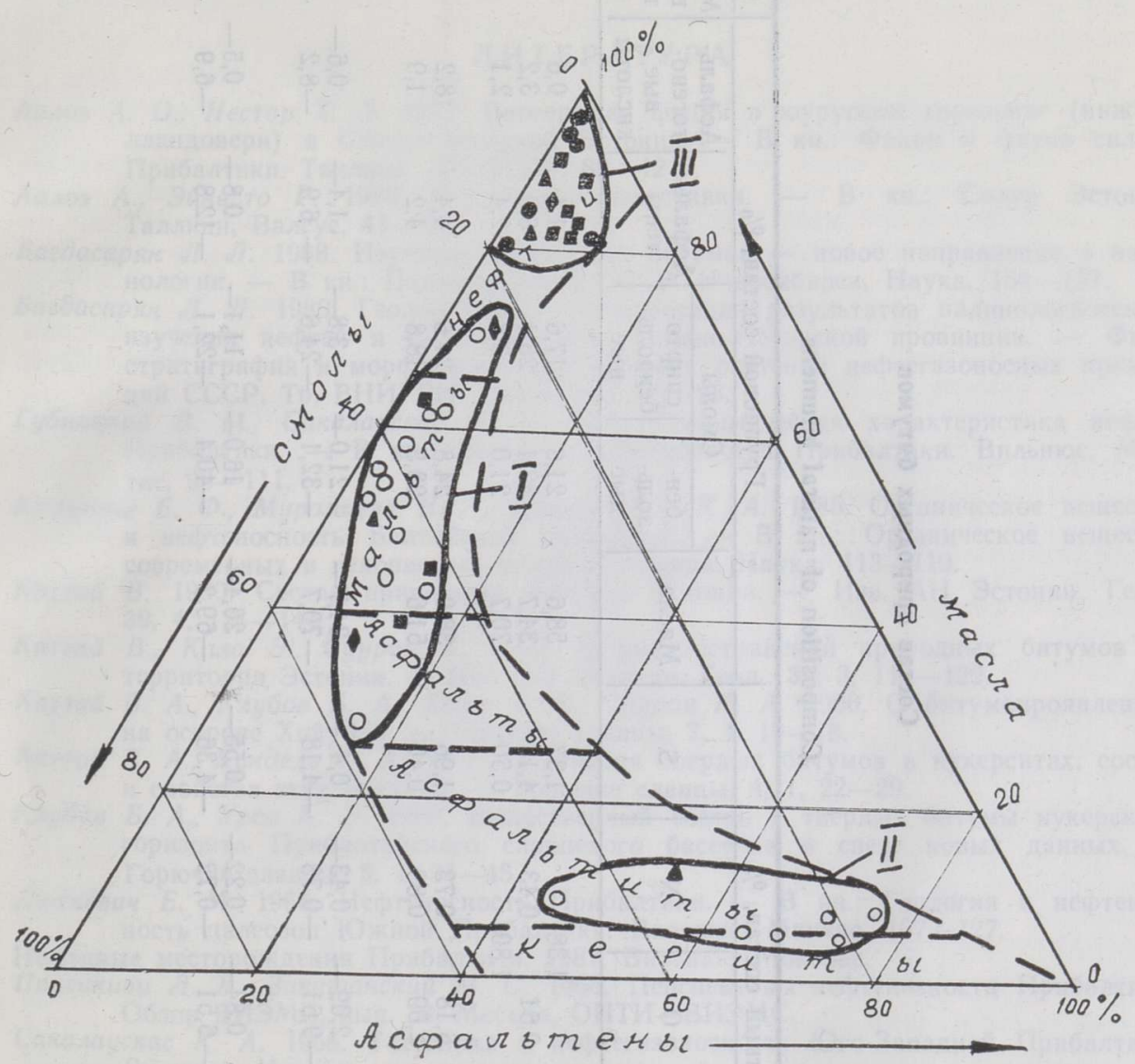

$\begin{array}{llllll}-1 & 4-2 & 0 & -3 & -4 & -5\end{array}$

Рис. 2. Расположение природных битумов (ПБ) Прибалтики на тригонограмме группового состава: масла-смолы-асфальтены. I - ПБ о-ва Хийумаа, II - ПБ северо-восточных регионов Эстонии (Каттай, 1990), III - нефти Центральной и Южной Прибалтики (Губницкий, Сакалаускас, 1973). Возраст вмещающих ПБ пород:

$$
1-\epsilon_{2}, 2-\mathrm{O}_{1}, 3-\mathrm{O}_{2}, 4-\mathrm{O}_{3}, 5-\mathrm{S}_{1-2} \text {. }
$$

Fig. 2. Distribution of natural bitumens (NB) of the East Baltic on the trigonogram of group composition: oil - tar-asphaltene. I - NB of Hiiumaa Island, II - NB of the northeastern areas of Estonia (Каттай, 1990), III - oil of the central and southern parts of the East Baltic (Губницкий, Сакалаускас, 1973). Age of the host rock: $1-\epsilon_{2}$, $2-\mathrm{O}_{1}, 3-\mathrm{O}_{2}, 4-\mathrm{O}_{3}, 5-\mathrm{S}_{1-2}$. 


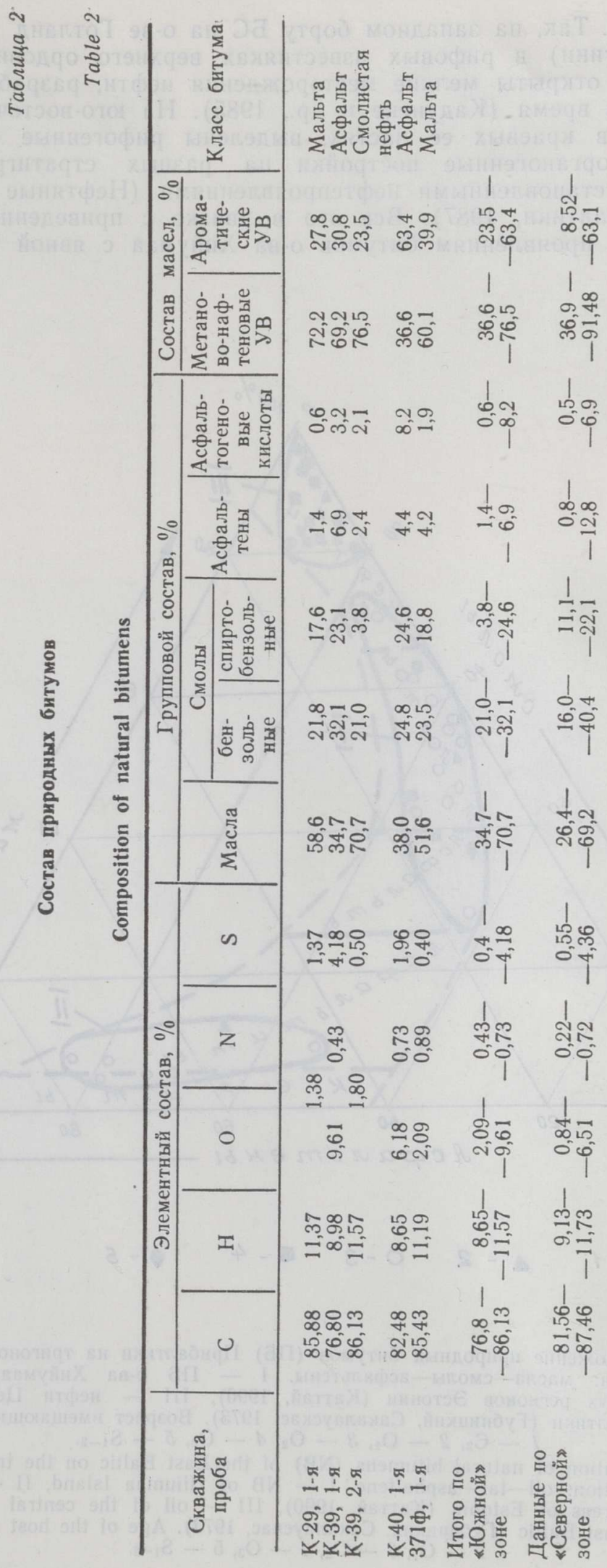


увеличения битумонасыщенности пород в направлении акватории моря не позволяет полностью согласиться с указанной оценкой перспектив нефтеносности краевых частей БС. Поэтому и шельфовая часть акватории Балтийского моря, западнее островов Сааремаа и Хийумаа, несомненно заслуживает первоочередного изучения. Перспективы здесь могут быть, видимо, связаны не со структурными, а с литолого-стратиграфическими ловушками - органогенными рифами в карбонатной толще силура-ордовика, а возможно также с линзами и участками выклинивания, размыва пластов песчаников, алевролитов и терригенных отложениях кембрия и нижнего ордовика.

\section{Л И Т Е Р А Т У Р А}

Аалоз А. О., Нестор Х. Э. 1977. Биогермная фация в юуруском горизонте (нижний лландовери) в Северо-Западной Эстонии. - В кн.: Фации и фауна силура Прибалтики. Таллинн, АН ЭССР, 89-121.

Аалоэ А., Эйнасто Р. 1970. Биогермные известняки. - В кн.: Силур Эстонии. Таллинн, Валгус, $41-46$.

Багдасарян Л. Л. 1988. Изучение природных битумов - новое направление в палинологии. - В кн.: Палинология в СССР. Новосибирск, Наука, 154-157.

Багдасарян Л. Л. 1989. Геологическая интерпретация результатов палинологического изучения нефтей и пластовых вод Тимано-Печорской провинции. - Фитостратиграфия и морфология спор древних растений нефтегазоносных провинций СССР. Тр. ВНИГРИ. Ленинград, 81-93.

Губницкий B. М., Сакалаускас K. A. 1973. Геохимическая характеристика нефтей Прнбалтики. - В кн.: Вопросы нефтеносности Прибалтики. Вильнюс, Минтис, 99-111.

Кадунене Е. Ф., Муромцева В. А., Сакалаускас К. А. 1985. Органическое вещество и нефтеносность Балтийской синеклизы. - В кн.: Органическое вещество современных и ископаемых осадков. Москва, Наука, 113-119.

Каттай B. 1990. Состав природных битумов Эстонии. - Изв. АН Эстонии. Геол., $39,4,133-141$.

Каттай В., Кала Э., Сууроя К. 1990. О распространении природных битумов на территории Эстонии. - Изв. АН Эстонии. Геол., 39, 3, 115-122.

Каттай В. А., Клубов Б. А., Кала Э. А., Сууроя К. А. 1990. О битумопроявлениях на острове Хийумаа. - Горючне сланцы, $7,1,10-18$.

Каттай В. А., Кундель Х. А. 1987. Включения твердых битумов в кукерситах, состав и свойства этих битумов. - Горючие сланцы, 4, 1, 22-29.

Клубов Б. А., Уров К. Э. 1988. Вещественный состав и твердые битумы кукерского горизонта Прибалтийского сланцевого бассейна в свете новых данных. Горючие сланцы, 5, 1, 34-45.

Люткевич Е. М. 1965. Нефтеносность Прибалтики. - В кн.: Геология и нефтеносность палеозоя Южной Прибалтики. Вильнюс, Минтис, 107-127.

Нефтяные месторождения Прибалтики. 1987. Вильнюс, Мокслас.

Паасикиви Л. Б., Закашанский М. С. 1965. Перспективы нефтеносности Прибалтики. Обзор ВИЭМС, вып. 34. Москва, ОНТИ-ВИЭМС.

Сакалаускас K. A. 1968. Тектоника и нефтегазоносность Юго-Западной Прибалтики. Вильнюс, Минтис.

Стумбур К. А., Биргер А. Я., Линчюс А. А., Пюви Х. С., Шапорев А. А. 1982. Полезные ископаемые. - В кн.: Геология республик Советской Прибалтики. Ленинград, Недра, 249-297.

Einpaul, A. 1961. Naftaotsimisest Hiiumaal XX sajandi esimesel veerandil. - Eesti Loodus, 4, 235-236.

Scupin, $H$. 1924. Zur Petroleumfrage in den baltischen Ländern. - Acta Univ. Tartu, A6, H. $11,13$.

Представил В. Пуура 


\section{UUSI ANDMEID BITUUMENI SISALDUSEST ALAMPALEOSOIKUMI KIVIMITES HIIUMAAL}

On kindlaks tehtud kaks bituumenite levikuala. Uks paikneb Hiiumaa põhjaosas̉ Kärdla struktuurist lääne pool, teine hõlmab Hiiumaa lõunaosa ja jätkub mandril. Esimeses piirkonnas on bituumenid seotud keskordoviitsiumi karbonaatkivimite kompleksiga, teises ülemordoviitsiumi ning alamsiluri kivimitega. Kõigil juhtudel on tegemist loodusliku bituumeniga, mille esinemisvorm - kas suurenenud tōrvasisaldusega nafta, malta või asfalt - sõltub hüpergeneetiliste muutuste astmest.

\section{Vello KATTAI, Boris KLUBOV, Lora BAGDASARYAN, and Kalle SUUROJA}

\section{NEW DATA ON THE BITUMEN-BEARING LOWER PALEOZOIC SEDIMENTS OF HIIUMAA ISLAND}

The paper belongs to a series of publications on natural bitumens (NB) of Estonia. The areal distribution and composition of NB on Hiiumaa Island are discussed considering the new data obtained in 1989-1990.

Two sublatitudinal zones can be distinguished in the greatest bitumen accumulation (Fig. 1). The "Northern" zone coincides in the east with the distribution area of the Kärdla structure; in the west it extends under the Baltic Sea. NB are related to the carbonate deposits from the Middle Ordovician Kukruse to Keila stages. NB finds have been made mostly from the interval of the section with the thickness of up to $40-50 \mathrm{~m}$; the top of bitumen-bearing sediments is inclined being from a few metres in the north up to $100-150 \mathrm{~m}$ in the middle of the island. In the region of the Kärdla structure, NB have been recorded in the post-crater carbonate formations of the Middle-Upper Ordovician Rakvere and Nabala stages.

The "Southern" zone of bitumen occurrences proceeds through the island from west to east; its continuation is observed also in continental Estonia. NB belong to the sediments of the Upper Ordovician Pirgu and Porkuni stages and to the Lower Silurian Juuru and Raikküla stages. The interval with NB is $10-40 \mathrm{~m}$ thick; the top of the layer inclines to the south at a depth from $10-20 \mathrm{~m}$ to $60-70 \mathrm{~m}$ from day surface. Middle Ordovician sediments have not yielded NB.

Bitumen saturation in the "Northern" as well as "Southern" zones is characterized by the development of patches and lines of impregnation, filling of pores, fine caverns and cracks with bitumen. Visually viscous NB are predominant, rarely solid and liquid NB occur. In the sediments of the Juuru Stage of the western part of the "Southern" zone, reef formations have been established where the cavities of corals occurring in boundstones are filled with bitumen of liquid to solid consistencies (Plate). In thin sections, several NB generations can be distinguished. Porous biohermal limestones act as typical lithological collectors.

Micropaleontological investigations have shown that the microfossils occurring in NB of Middle Ordovician sediments are characteristic only of rocks of this age and their concentration is higher in bitumen than in the host rock. This can be explained by a prolonged lateral migration of oil along the seam. The composition of microfossils occurring in bitumens of Lower Silurian rocks is not homogeneous. Here are found also Middle Ordovician species; this may testify to the supply of NB from older sediments.

NB of the "Northern" and "Southern" zones have similar organic compositions (Table 2). They may be treated as components of a normal hypergene order of oil changes: tarry oil-maltha-asphalt.

The marginal areas of the Baltic syneclise used to be considered unpromising as oil-bearing regions. Yet, oil recovery from small deposits in reef limestones of Gotland Island at the western border of the syneclise, discovery of new oil occurrences in reef structures at the southeastern border of the syneclise, and those of oil bitumen on Hiiumaa Island call this opinion in question. Additional investigations are needed first of all of the part of the shelf of the Baltic Sea west of Saaremaa and Hiiumaa islands. 